\title{
Tailoring nostoclide structure to target the chloroplastic electron transport chain
}

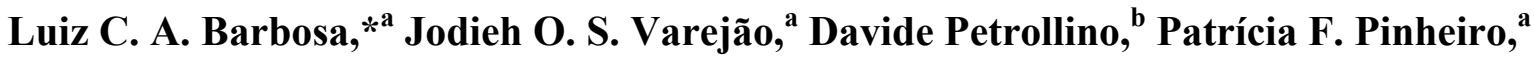 \\ Antônio J. Demuner, ${ }^{a}$ Célia R. A. Maltha, ${ }^{a}$ and Giuseppe Forlani*b \\ ${ }^{a}$ Department of Chemistry, Federal University of Viçosa, Avenida P.H. Rolfs, CEP 36570-000, \\ Viçosa, MG, Brazil, and ${ }^{b}$ Department of Biology and Evolution, University of Ferrara, via L. \\ Borsari 46, I-44100 Ferrara, Italy \\ E-mail: lcab@ufv.br and flg@unife.it
}

\section{Dedicated to Prof. Pawel Kafarski to honor the achievements within his career}

\begin{abstract}
Aiming to improve their effectiveness, three modifications were introduced into the structure of the natural phytotoxins nostoclides, leading to the synthesis of novel 3-benzyl-4-isopropyl-5(arylmethylene)furan-2(5H)-ones, 3-benzyl-5-(furan-2-ylmethylene)furan-2(5H)-ones, and 3,4dihalo-5-arylidenefuran-2(5H)-ones. All compounds were characterized by $\mathrm{IR},{ }^{1} \mathrm{H}$ and ${ }^{13} \mathrm{C} \mathrm{NMR}$, NOEDIF, COSY, HETCOR and MS spectrometry. Increasing the length of the molecule was found to reduce the ability to interfere with ferricyanide reduction by isolated chloroplasts. The addition of an isopropyl moiety into the heterocyclic ring, as in naturally-occurring nostoclides, did not influence the inhibitory potential. Also the replacement of the electron-drawing phenyl substituent with two halogen residues did not improve the resulting activity. However, both latter modifications influenced the interaction with the photosynthetic machinery. These analogues could therefore represent novel leads to be explored toward the development of new herbicides targeting the chloroplastic electron transport chain.
\end{abstract}

Keywords: Energy transfer inhibitors, herbicides, Hill reaction, nostoclide analogues, electron transport chain inhibitors, $\gamma$-alkylidenebutenolides

\section{Introduction}

Increasing public concern for the environmental pollution deriving from agricultural practice strictly requires that modern agrochemicals would be endowed with low persistence. Intensive efforts have been undertaken to discover new compounds with favorable environmental and safety features to selectively control weeds. ${ }^{1,2}$ The identification of novel herbicides is highly 
desirable also to overcome weed resistance, rapidly raised as a consequence of the severe selective pressure imposed by a continuous application of active ingredients with the same biochemical mode of action. ${ }^{3}$ However, the unfavorable economics of herbicide development, mainly due to increasing regulatory requirements, is greatly limiting industrial discovery programs. ${ }^{4}$ Moreover, many active principles that are currently in use came from a small set of molecular scaffolds, whose functional lifetime has been extended by synthetic tailoring (e.g. triazines, sulfonylureas and imidazolinones). ${ }^{5}$ Because of the exponential emergence and diffusion of herbicide resistance, the discovery of new scaffolds is mandatory. The exploitation of natural products might combine the need of new chemical structures with a suitable susceptibility to microbial degradation. ${ }^{6}$

Among the naturally-occurring phytotoxins discovered to date are the nostoclides (Figure 1), $\gamma$-alkylidenebutenolides produced by Nostoc $s p .^{7}$ The nostoclides resemble cyanobacterin, a lactone isolated from the blue-green alga Scytonema hofmanni, which inhibits the growth of several eukaryotic algae and mono- and dicotyledonous angiosperms by interfering with the photosynthetic electron transport. ${ }^{8}$
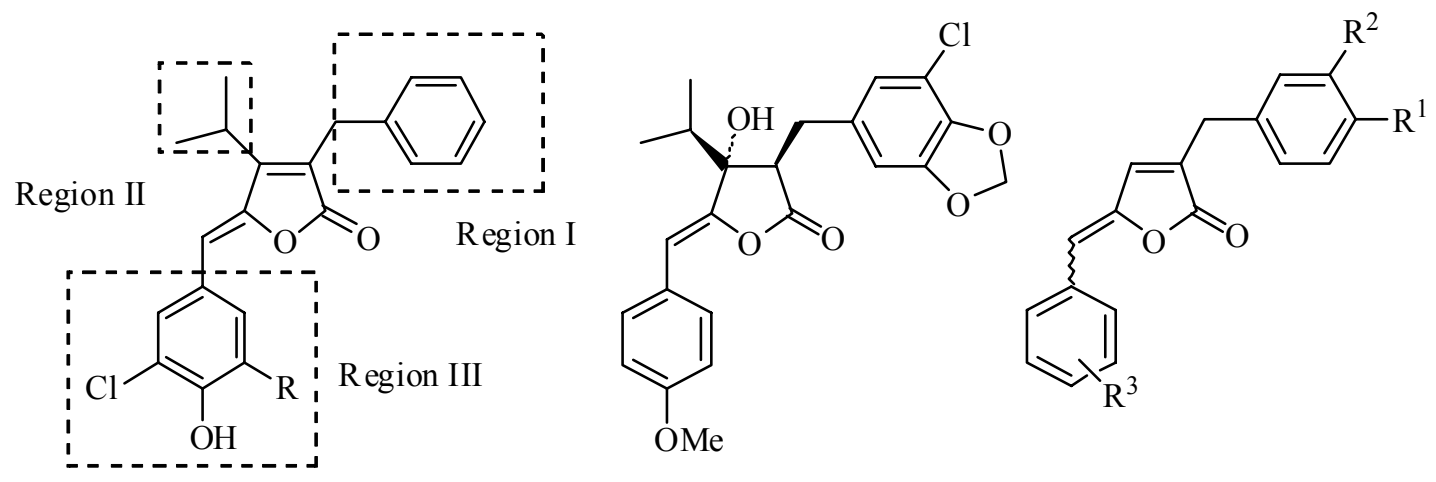

$$
\begin{aligned}
& \text { 1, Natural nostoclides } \\
& \mathrm{R}=\mathrm{Cl} \text {, nostoclide I } \\
& \mathrm{R}=\mathrm{H} \text {, nostoclide II }
\end{aligned}
$$

2, Cyanobacterin

3, Nostoclides analogues

$$
\begin{aligned}
& \mathrm{R}^{1}=\mathrm{R}^{2}=\mathrm{H} \\
& \mathrm{R}^{1}=\mathrm{Br}, \mathrm{R}^{2}=\mathrm{H} \\
& \mathrm{R}^{1}=\mathrm{H}, \mathrm{R}^{2}=\mathrm{Cl} \\
& \mathrm{R}^{3}=\text { various substituents }
\end{aligned}
$$

Figure 1. Naturally-occurring phytotoxins and chemically synthesized analogues. 1: nostoclides; 2: cyanobacterin; 3: 3-benzyl-5-(arylmethylene)furan-2(5H)-ones designed using nostoclides as a lead structure. 9,10

When a group of twelve 3-(4-bromobenzyl)-5-(arylmethylene)furan-2(5H)-ones were synthesized using the nostoclides as a lead structure, several of them were indeed found to inhibit the light-driven reduction of ferricyanide by isolated spinach chloroplasts, the so-called Hill reaction. ${ }^{9}$ A second series of 34 non-brominated analogues showed better inhibitory properties, but none of them was capable of completely suppressing the Hill reaction, mostly due to a poor 
water solubility. ${ }^{10}$ The inhibition brought about by the most active brominated analogues was found to be progressively reversed when increasing $\mathrm{NH}_{4} \mathrm{Cl}$ concentrations dissipated the proton gradient across the thylakoid membrane. ${ }^{9}$ These results suggest that the synthetic nostoclide analogues may act by inhibiting phosphorylation in chloroplasts, working as energy transfer inhibitors through an interaction with the coupling factor, $\mathrm{CF}_{0}-\mathrm{CF}_{1}$. This mode of action differs from that of commercial herbicides targeting photosynthesis, most of which interact with the electron transport chain, ${ }^{11}$ but is similar to that reported for other naturally-occurring phytotoxins. ${ }^{12}$ A thorough quantitative structure-activity relationship analysis suggested that the most relevant molecular property modulating the inhibitory potential of this class of compounds is their molecular polarity, as expressed by the dipole moment. ${ }^{13}$

A certain degree of lipophilicity is usually required for a photosynthetic inhibitor, given that in order to exert its effect, it needs to diffuse through both the plasmalemma and the chloroplast envelopes. ${ }^{14}$ In several cases the presence of a hydrocarbon side chain has been reported to greatly impact the activity of a given scaffold, as it provides the required lipophilicity. ${ }^{15}$ But the opposite is also true, because sufficient hydrophilicity is needed to allow herbicides to be translocated within the plants and reach their target inside the chloroplast.

To obtain more effective derivatives, some modifications were designed into the scaffold of nostoclides. As shown in Figure 1, their $\gamma$-alkylidenebutenolide core has three substituent groups (Regions I, II, and III). In this work we report the synthesis of compounds where these regions were modified in order to evaluate the effect of each group on the resulting ability to interfere with the photosynthetic apparatus.

\section{Results and Discussion}

\section{Synthesis}

Compound 4, used as starting material for the synthesis of $\mathbf{6}$, is commercially available, but due to its high price (U\$200/gram) it was prepared from the cheap furfuraldehyde by oxidation with hydrogen peroxide followed by basic hydrolysis. ${ }^{16}$ Compound 4 was then converted into the phosphorous intermediate 5 in $49 \%$ yield using a methodology previously described. ${ }^{9}$ Further treatment of 5 with BuLi followed by capture of the furyllithium formed with benzylbromide and acid hydrolysis of the intermediate, resulted in the formation of 6 in $69 \%$ yield (Scheme 1). This compound is not new and as a consequence the full spectroscopic data are not reported, as they were in full agreement with previously reported data. ${ }^{10,17}$

In order to evaluate the influence of the isopropyl group on the biological activity, the intermediate 9 was prepared as shown in Scheme 1. Compound 9 has been previously prepared by Bellina and Rossi. ${ }^{18}$ They introduced the isopropyl group by reaction of 7 with toxic prop-2eniltributyltin, followed by the hydrogenation of the propenyl unit using expensive Wilkinson catalyst. This two-step procedure resulted in compound $\mathbf{8}$ in $74 \%$ yield. Further palladium coupling of the benzyl group resulted in 9. As the overall yield obtained was only $26.6 \%$, we 
developed an alternative procedure for the synthesis of 9. In our synthesis, compound 7 was reacted with isopropyl magnesium bromide in the presence of $\mathrm{CuI}$ or $\mathrm{CuBr}$. $\mathrm{Me}_{2} \mathrm{~S}$ and using the Lewis acids $\mathrm{BF}_{3} . \mathrm{Et}_{2} \mathrm{O}$ or $\mathrm{TMSCl}$ as a catalyst and $\mathrm{THF}$ or diethyl ether as a solvent. The reaction conditions were optimized and compound 8 was produced in one step from 7 in $93 \%$ yield upon the use of $\mathrm{CuBr}^{-\mathrm{Me}_{2} \mathrm{~S}}(1 \mathrm{eq})$ and $\mathrm{BF}_{3} \cdot \mathrm{Et}_{2} \mathrm{O}(2 \mathrm{eq})$. The best solvent for this reaction was THF, whereas diethyl ether did not afford the required product in good yield.

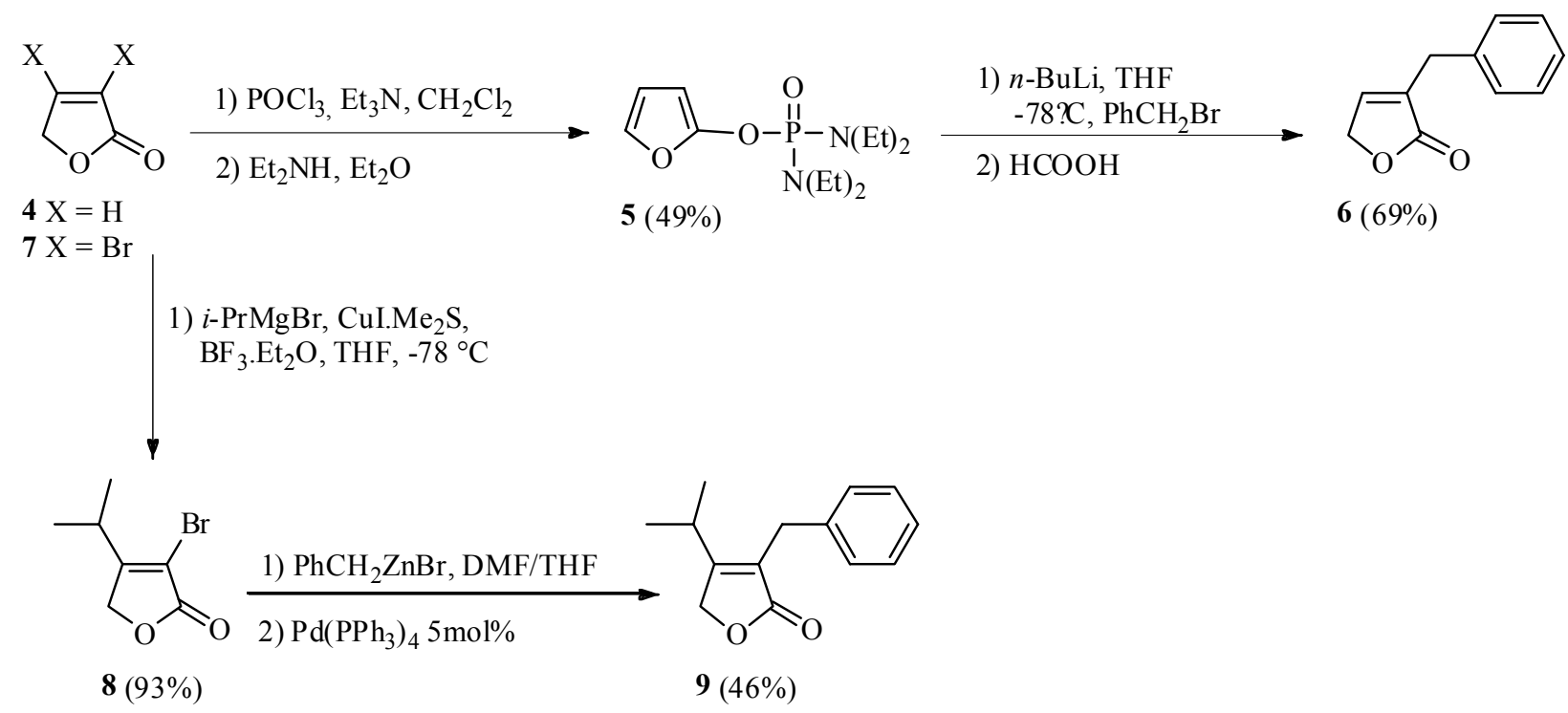

Scheme 1. Synthesis of precursor compounds 6 and 9.

Further introduction of the benzyl group at the alpha position was possible by means of the Negishi coupling ${ }^{19}$ and the best experimental conditions led to the required product in $46 \%$ yield. The spectroscopic data (not shown) obtained for 9 were in full agreement with those previously reported. ${ }^{17,18}$

With compound 6 and 9 in hands, new nostoclide analogues were prepared (Scheme 2). The first series prepared consisted in compounds 11-16, all containing a furanmethylene unit attached to the lactone ring. The rationale for the introduction of the furan ring was based on the results previously reported that the biological activity was associated with the polarity of the compounds. ${ }^{13}$ We anticipated that as furyl unit is more polar than the phenyl ring, the introduction of this heteroaromatic moiety could result in more active substances.

The appendage of the C5 substituents at compounds 6 and 9 can be achieved in two steps by aldol condensation followed by elimination of water $^{20}$ or by a one-pot arylmethylenation procedure developed by Boukouvalas ${ }^{17,21}$ and several procedures were reported for the aldol reaction involving butenolide 4 . Initially, we tried the new condensation protocol described by $\mathrm{Xu}$ et al., ${ }^{22}$ but contrary to what they reported, only one product was isolated from the hydrolysis of the butenolide. Then reaction of $\mathbf{6}$ with furfural in the presence of tert-butyldimethylsilyltrifluoro-methanesulfonate, and diisopropyl-ethylamine followed by treatment of the silyl 
ether generated in situ with $\mathrm{DBU}^{17}$, led to the formation of compound $\mathbf{1 1}$ in $58 \%$ yield. In this case only the $Z$ isomer was isolated as it was observed for the preparation of its benzylidene analogues 24-32 (Scheme 2). The confirmation of the structure of 11 was based on its spectroscopic data, including Nuclear Overhauser Effect difference spectroscopy (NOEdiff) that revealed a correlation between $\mathrm{H}-6$ and $\mathrm{H}-4$, with $6 \%$ increase of the signal of $\mathrm{H}-4$, in agreement with the $Z$ stereochemistry.

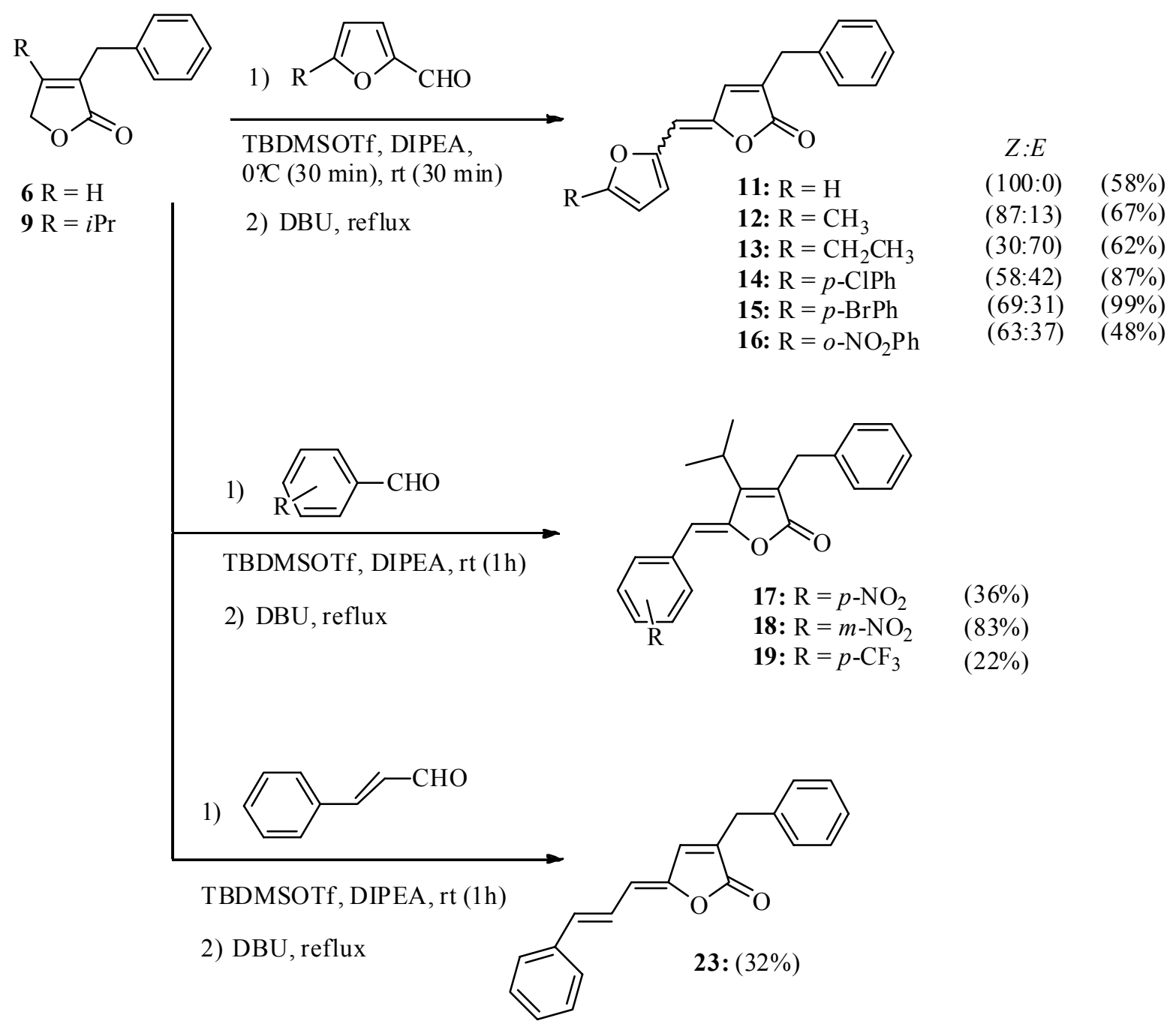

Scheme 2. Synthesis of compounds 11-19 and 23.

Compounds 12 to $\mathbf{1 6}$ were prepared using the same condensation reaction conditions but in such cases mixtures of $Z / E$ isomers were formed. The ratio of $Z / E$ varied from 87:13 in the case of 12 to 30:70 for compound 13. All isomers were separated by HPLC analysis and fully characterized, except the $E$ isomer of 12, as it degraded during the purification steps. For all $Z$ isomers a NOE effect was observed between H-6 and H-4 as in the case of compound 11. In the case of the $E$ isomers, no NOE effect was observed. 
In a previous work we have shown that nostoclide analogues with electron withdrawing groups in the benzylidene rings were among the most active. ${ }^{9,10}$ So, to evaluate the influence of the isopropyl group, present in the natural nostoclides, compound 9 was converted into benzylidene lactones 17 (36\%), 18 (83\%), and 19 (22\%). A few attempts to improve the yields of 17 and 19 were carried out, but at this point of the work, we concentrated our effort in the production of enough material for biological investigation. All compounds were produced as $Z$ isomer, being that a nuclear NOE effect was observed between H-6 and hydrogen of group isopropyl, and even for the low yield reactions.

Compound 23 was prepared from 3-phenylpropenal in 32\% yield under the same conditions used before. No attempt was made to optimize the yield of this product as our major goal was to evaluate the influence of the extra $\mathrm{C}=\mathrm{C}$ carbon unit on the biological activity as this has not been investigated in previous works. ${ }^{9,10}$

To evaluate if the benzyl unit at carbon 3 of the furanone ring is essential for the biological activity, we prepared three halogenated analogues 20-22. They were synthesized from 3,4dibromofuran-2(5H)-one 7 and 3,4-dichlorofuran-2(5H)-one 10 in $13 \%$ to $65 \%$ yields, as depicted in Scheme 3, using the same alkylidenation protocol already described. Although compound 22 was prepared from the activated electron poor aldehyde, it was isolated in very small yield. This result is not easily explained considering that the more electron-rich aldehyde 3,4-dioxalenebenzaldehyde, resulted in high yield condensation products $\mathbf{2 0}$ and $21 .{ }^{20}$

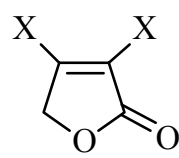

$\mathrm{X}=\mathrm{Br} 7$

$\mathrm{X}=\mathrm{Cl} \quad \mathbf{1 0}$

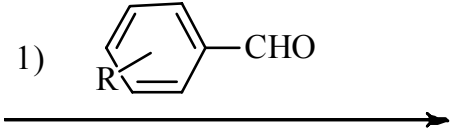

TBDMSOTf, DIPEA, rt (1h)

2) DBU, reflux

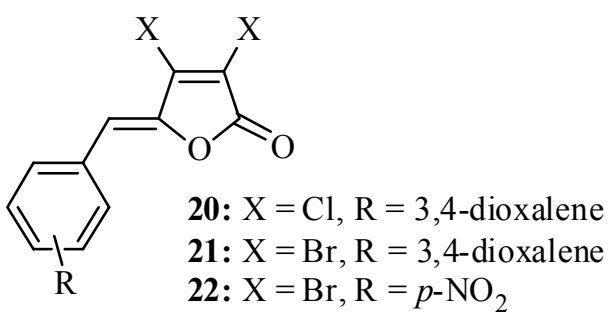

(70\%)

$(13 \%)$

Scheme 3. Synthesis of compounds 20-22.

The stereochemistry of compounds $\mathbf{2 0 - 2 2}$ is $Z$ since the $E$ isomer would be formed via an intermediate less stable due to the repulsion between the bromine at beta position and the aryl group. $^{21}$

\section{Biological activity}

The ability of these three small groups of nostoclide analogues to interfere with the light-driven ferricyanide reduction by osmotically swollen spinach chloroplasts was then investigated. The results were compared with those obtained with the corresponding 3-benzyl-5-(arylmethylene) furan-2(5H)-one counterparts (Figure 2), whose biological activity had been previously characterized. ${ }^{9,10}$ 
Data concerning compounds 14, 15 and 23 (Table 1) clearly suggest that the increase of the length of the molecule does not increase the inhibitory potential. Indeed, the inhibition brought about by poorly active nostoclides was not significantly improved, whereas that of an active derivative lowered as a consequence. On this basis, the higher effectiveness found for several derivatives bearing bulky substituents ${ }^{9,10}$ has most likely to be interpreted as a consequence of the resulting effect on the electronic distribution, and not of an insufficient spanning of the scaffold across the thylakoid membrane.

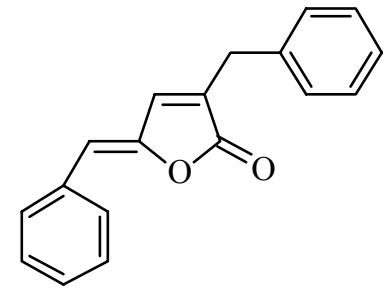

24

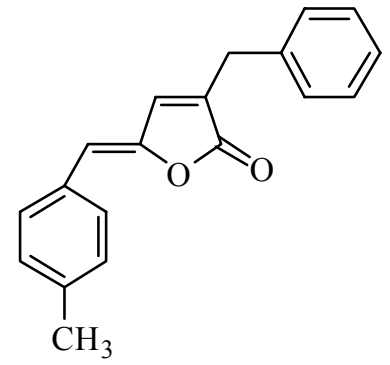

27

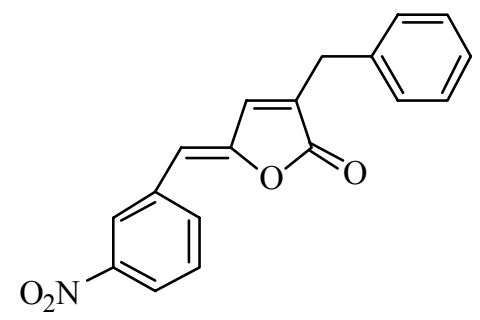

30

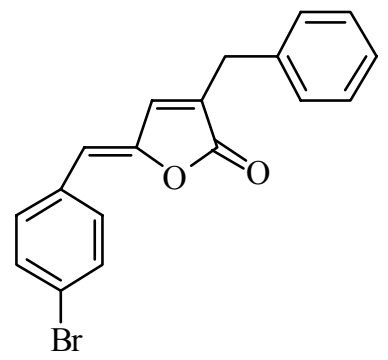

25

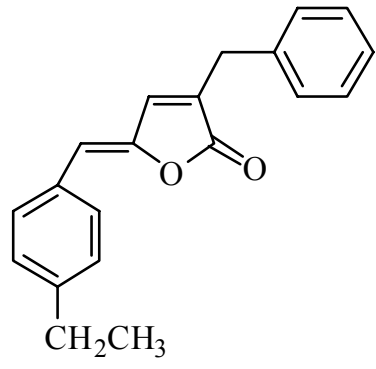

28

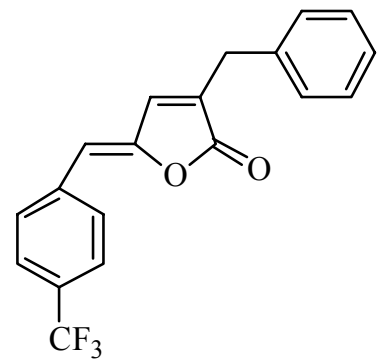

31

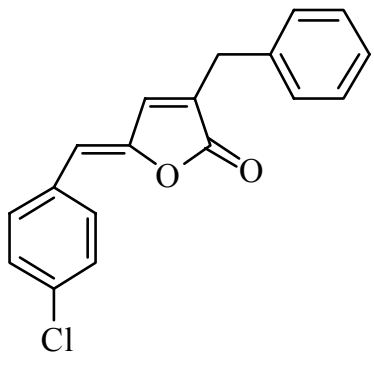

26

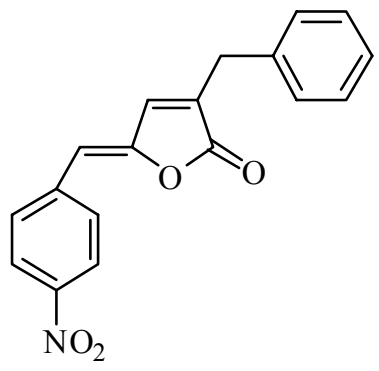

29

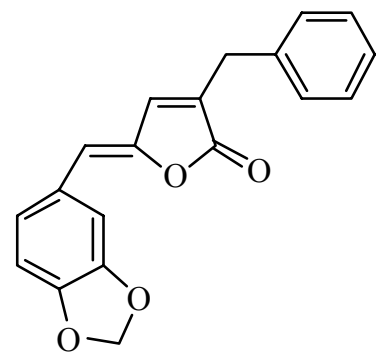

32

Figure 2. Nostoclide analogues previously synthesized and tested for the ability to interfere with the photosynthetic electron transport chain. ${ }^{9,10}$ These compounds were included for comparison. 
Table 1. Concentrations able to 50\%-inhibit the photosynthetic electron transport chain, measured as the ability to reduce ferricyanide by functionally intact spinach chloroplasts

\begin{tabular}{cccc}
\hline Compound & $\mathrm{IC}_{50}(\mu \mathrm{M})$ & $\begin{array}{c}\text { Nostoclide } \\
\text { analogue }\end{array}$ & $\mathrm{IC}_{50}(\mu \mathrm{M})$ \\
\hline $\mathbf{1 4}$ & $380 \pm 27$ & $\mathbf{2 6}$ & $>1000$ \\
$\mathbf{1 5}$ & $>1000$ & $\mathbf{2 5}$ & $473 \pm 42$ \\
$\mathbf{2 3}$ & $118 \pm 23$ & $\mathbf{2 4}$ & $19.7 \pm 3.9$ \\
$\mathbf{1 7}$ & $2.9 \pm 0.7$ & $\mathbf{2 9}$ & $1.7 \pm 0.7$ \\
$\mathbf{1 8}$ & $190 \pm 23$ & $\mathbf{3 0}$ & $23.1 \pm 13.3$ \\
$\mathbf{1 9}$ & $15.8 \pm 5.1$ & $\mathbf{3 1}$ & $8.3 \pm 2.3$ \\
$\mathbf{2 0}$ & $>1000$ & $\mathbf{3 2}$ & $>1000$ \\
$\mathbf{2 1}$ & $>1000$ & $\mathbf{3 2}$ & $>1000$ \\
$\mathbf{2 2}$ & $6.2 \pm 0.6$ & $\mathbf{2 9}$ & $1.7 \pm 0.7$ \\
\hline
\end{tabular}

Data are compared with those obtained with the corresponding nostoclide analogues previously synthesized and evaluated as Hill reaction inhibitors. ${ }^{9,10}$ Data presented for compounds 14 and 15 refer to the $E$ isomers; the experiment was performed also with the $Z$ isomers, obtaining very similar patterns (data not shown).

With respect to compounds $\mathbf{1 7 - 1 9}$, the presence of an isopropyl moiety in the heterocyclic ring, as in natural nostoclides and cyanobacterin, did not exceedingly vary the resulting ability to inhibit ferricyanide reduction (Table 1). This allows us to rule out the possibility that the remarkably higher inhibition brought about by the latter natural toxin ${ }^{8}$ may be due to this feature. The result seems also consistent with previous data showing that any change of the substituents of the phenyl ring in the cyanobacterin molecule produced less phytotoxic analogues, even if those of the furan ring remained unchanged. ${ }^{23}$

Also in the case of compounds 20-22 the modifications introduced in the scaffold failed to increase the inhibitory activity. On the contrary, a slight decrease was evident for compound 22 (Table 1). However, this was paralleled by a concomitant increase of its water solubility, one that allows achieving actually high concentrations in the reaction mixture (not shown). Over a certain threshold, at about $2 \mu \mathrm{M}$, the low solubility of the 3-benzyl-5-(arylmethylene)furan-2(5H)-one counterpart indeed caused the resulting inhibitory effect to rapidly reach a plateau and not increase further. The lack of a dose-effect relationship for the active compounds at high rates is the reason why the nostoclide analogues previously synthesized were unable to completely suppress the Hill reaction. ${ }^{9,10}$ On the contrary, over the whole range tested compound 22 was found to progressively inhibit ferricyanide reduction, which at concentrations exceeding $20 \mu \mathrm{M}$ was almost undetectable. 
This preliminary characterization was performed by measuring ferricyanide reduction under basal conditions. To gain more information about their mode of action, the inhibitory properties of the two most active compounds $\mathbf{1 7}$ and $\mathbf{2 2}$ were assessed also under phosphorylating or uncoupled conditions. In the presence of substrates of ATP synthase, both compounds retained their ability to inhibit the Hill reaction, and the residual percent activity did not differ significantly from that evaluated under basal conditions. Unexpectedly, the same result was found with the uncoupled electron flow (data not presented).

This behavior differs from that previously found for brominated 3-benzyl-5-(arylmethylene)furan-2(5H)-one lactones, whose effect was progressively reverted when increasing levels of an uncoupler were included into the reaction mixture. ${ }^{9}$ On this basis, those nostoclide analogues were supposed to be able to interfere with phosphorylation in chloroplasts, acting as energy transfer inhibitors through an interaction with the coupling factor, $\mathrm{CF}_{0}-\mathrm{CF}_{1}$. To verify this aspect, the inhibition brought about by compounds $\mathbf{1 7}$ and $\mathbf{2 2}$ was also assessed at varying ammonia concentration. As a term of comparison, two 3-benzyl-5-(arylmethylene)furan-2(5H)ones (either brominated or not) also bearing a nitroso moiety in the phenyl ring were included in the experimental plan. Results (Figure 3) confirmed a difference among these compounds. Consistently with previous findings, the effect of the brominated 3-benzyl-5(arylmethylene)furan-2(5H)-one was completely relieved when the concentration of the uncoupler was high enough to dissipate the transmembrane proton gradient. Interestingly, the inhibition brought about by the non-brominated analogue was reversed only in part, whereas that of both the new compounds was insensitive at all to the presence of ammonia. These data therefore suggest that, at varying the chemical structure of nostoclide scaffold, the interaction with the photosynthetic machinery also changes. The brominated analogue most likely interacts only with the coupling factor. The non-brominated derivative seems to interact both with the coupling factor and the electron transport chain, since it is still effective under uncoupling conditions, although to a lower extent. Compounds 17 and 22 may on the contrary interfere only with the electron transport chain, being their inhibitory activity substantially unchanged under all the experimental conditions employed. Because this mode of action is the same of commercial herbicides targeting photosynthesis, ${ }^{11}$ their effectiveness in vivo could be higher than that of the 3-benzyl-5-(arylmethylene)furan-2(5H)-one lactones previously synthesized. Experiments are currently in progress to verify this possibility. 

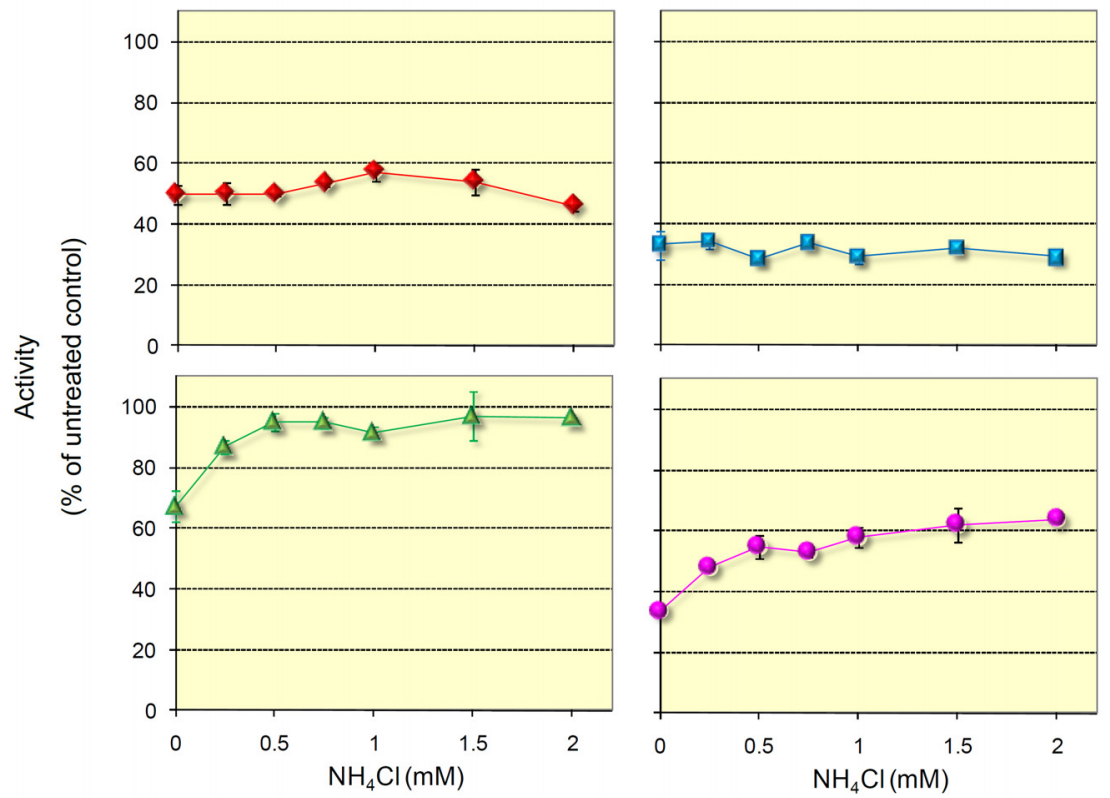

Figure 3. Effect of a fixed concentration of compounds $17(5 \mu \mathrm{M} \diamond)$ and $22(10 \mu \mathrm{M} \square)$ on the photosynthetic electron transport chain at increasing ammonia concentration. Data are shown together with those obtained with the corresponding brominated (10 $\mu \mathrm{M}$ compound $30 \Delta)$ or non-brominated (2.5 $\mu \mathrm{M}$ compound 29 ) 3-benzyl-5-(arylmethylene)furan-2(5H)-one lactones also bearing a nitroso moiety in the phenyl ring. Results are expressed as percentage of those obtained with the same $\mathrm{NH}_{4} \mathrm{Cl}$ concentration in the absence of any inhibitor.

\section{Experimental Section}

General. Solvents and amines were purified as described by Perrin and Armarego. ${ }^{27}$ All other reagents were purchased from Sigma Aldrich (Milwaukee, WI, USA) and utilized without further purification. Lactone 4 was synthesized with 44\% yield, from furfural, as previously described. ${ }^{10}$ The compounds 7 and $\mathbf{1 0}$ were prepared in $75 \%$ and $60 \%$ yield, respectively from mucohalic acid according to the literature ${ }^{24}$ and lactones 6 and 9 were synthesized as previously described. $^{10,17}$ Commercially available $n$-butyllithium hexane solutions $\left(1.4 \mathrm{~mol} \mathrm{\textrm {L } ^ { - 1 }}\right)$ were titrated prior to use. ${ }^{25}$ Melting points are uncorrected and were obtained from an MQAPF-301 melting point apparatus (Microquimica, Brazil). Analytical thin layer chromatography analysis was conducted on aluminum-packed precoated silica gel plates. Column chromatography was performed over silica gel (70-230 or 230-400 mesh). Infrared spectra were recorded on a PerkinElmer Paragon 1000 FTIR spectrophotometer or Varian 660-IR FTIR with accessory PIKE Gladi ATR, using potassium bromide $(1 \% \mathrm{w} / \mathrm{w})$ disks, or thin liquid film on $\mathrm{NaCl}$ discs. Mass spectra were recorded on a Shimadzu GCMS-QP5050A instrument by direct insertion, EI mode (70 eV). The ${ }^{1} \mathrm{H}$ and ${ }^{13} \mathrm{C}$ NMR spectra were recorded on a Varian Mercury 300 spectrometer at 300 and 
$75 \mathrm{MHz}$, respectively, using $\mathrm{CDCl}_{3}$ as solvent and TMS as internal standard, unless otherwise stated.

The HPLC purifications were performed on a Shimadzu LC-10A equipment, using an UV detector at $292 \mathrm{~nm}$ and a preparative column Shim-Pack $20 \times 250 \mathrm{~mm}(15 \mu \mathrm{m})$. The mobile phase for all the purifications was dichloromethane and hexane and flow of $6 \mathrm{~mL} / \mathrm{min}$ and the injection volume was $200 \mu \mathrm{L}$.

(Z)-3-Benzyl-5-(furan-2-ylmethylene)furan-2(5H)-one (11). To a two-neck round-bottom flask under nitrogen atmosphere were added 3-benzylfuran-2(5H)-one 6 (100 mg, $0.57 \mathrm{mmol})$, dichloromethane (DCM, $3 \mathrm{~mL})$, TBDMSOTf (170 $\mu \mathrm{L}, 0.74 \mathrm{mmol})$, DIPEA (310 $\mu \mathrm{L} ; 1.2 \mathrm{mmol})$ and 2-furaldehyde $(0.12 \mathrm{~g} ; 1.2 \mathrm{mmol})$. The reaction mixture was stirred for $30 \mathrm{~min}$ at $0{ }^{\circ} \mathrm{C}$ and a further $30 \mathrm{~min}$ at room temperature. After DBU $(120 \mu \mathrm{L}, 1.2 \mathrm{mmol})$ was added, the reaction mixture was refluxed for an additional $1 \mathrm{~h}$ before the addition of dichloromethane $(70 \mathrm{~mL})$. The resulting organic layer was washed with $3 \mathrm{~mol} \mathrm{~L}^{-1} \mathrm{HCl}$ aqueous solution $(2 \times 25 \mathrm{~mL})$ and brine $(25 \mathrm{~mL})$. After separation, the organic layer was dried over $\mathrm{MgSO}_{4}$, filtered, and concentrated under reduced pressure. The crude residue was purified by flash column chromatography on silica-gel using DCM /hexane $(2: 1 \mathrm{v} / \mathrm{v})$ as elutant to yield the required product as an yellow solid in 58\% yield. Mp 76.1-77.0 ${ }^{\circ} \mathrm{C}$, IR (KBr) 3086, 3062, 3028, 2922, 1763, 1650, 1603, 1560, 1474, 1335, 1272, $1078 \mathrm{~cm}^{-1}$. ${ }^{1} \mathrm{H}$ NMR (300 MHz, $\left.\mathrm{CDCl}_{3}\right), \delta 3.72(\mathrm{~s}, 2 \mathrm{H}, \mathrm{H}-7), 5.91(\mathrm{~m}, 1 \mathrm{H}, \mathrm{H}-$ 6), 6.52 (ddd, 1H, H-4"; $J_{4 " / 3 "} 3.4 \mathrm{~Hz}, J_{4} " / 5 " 1.8 \mathrm{~Hz}, J_{4} " / 60.6 \mathrm{~Hz}$ ), 6.92 (td, 1H, H-4; $J_{4 / 7} 1.5 \mathrm{~Hz}, J_{4 / 6}$ $0.3 \mathrm{~Hz}$ ), 6.99 (dl, 1H, H-3"; $J_{3 " / 4}$ " $3.4 \mathrm{~Hz}$ ), 7.24-7.38 (m, 5H, Ph), 7.47 (dd, 1H, H-5"; $J_{5}$ "/4" 1.8 $\mathrm{Hz}, J_{5}$ "/3" $\left.0.9 \mathrm{~Hz}\right) .{ }^{13} \mathrm{C} \mathrm{NMR}\left(75 \mathrm{MHz}, \mathrm{CDCl}_{3}\right), \delta 32.0$ (C-7), 101.2 (C-6), 113.2 (C-4"), 114.9 (C-3”), 127.2 (C-4'), 129.1 (C-3'/5'), 129.1 (C-2'/6'), 132.9 (C-3), 137.5 (C-1'), 138.5 (C-4), 144.0 (C-5’), 145.7 ( C-5), 149.3 (C-2”), 170.2 (C-2). HRMS (ESI) Calcd for $\mathrm{C}_{16} \mathrm{H}_{12} \mathrm{NaO}_{3}(\mathrm{M}+\mathrm{Na}), 275.0679$; Found, 275.0678 .

Compounds 12-16 were prepared by employing a procedure similar to that described for compound 11. Compounds $\mathbf{1 7 - 2 3}$ were prepared as previously described. ${ }^{9,10}$ The synthesized compounds were fully characterized by IR, NMR $\left({ }^{1} \mathrm{H}\right.$ and $\left.{ }^{13} \mathrm{C}\right)$, COSY, HETCOR, NOEDIF and MS spectrometry. Structures for the remaining compounds are supported by the following spectroscopic data.

(Z)-3-Benzyl-5-(5-methylfuran-2-ylmethylene)furan-2(5H)-one (12a). Yield 67\% (Z:E 87:13), diastereoisomers obtained after purification by column chromatography, eluent $\mathrm{DCM} /$ hexane $(2: 1 \mathrm{v} / \mathrm{v})$. Yellow solid, $\mathrm{mp} 87.4-87.7{ }^{\circ} \mathrm{C}$, isolated by HPLC, eluent DCM /hexane (1:1 v/v). IR (neat) 3062, 3028, 2921, 1761, 1650, 1584, 1517, 1495, 1429, 1381, 1276, 1129 , 1075, $1024 \mathrm{~cm}^{-1} .{ }^{1} \mathrm{H}$ NMR $\left(300 \mathrm{MHz}, \mathrm{CDCl}_{3}\right), \delta 2.33\left(\mathrm{~s}, 3 \mathrm{H}, \mathrm{CH}_{3}\right), 3.71(\mathrm{~s}, 2 \mathrm{H}, \mathrm{H}-7), 5.84(\mathrm{~s}$, 1H; H-6), 6.12-6,14 (m, 1H, H-4”), 6.89-6.90 (m, 2H, H-4, H-3"), 7.24-7.35 (m, 5H, Ph). ${ }^{13} \mathrm{C}$ NMR (75 MHz, $\mathrm{CDCl}_{3}, \delta 14.1\left(\mathrm{CH}_{3}\right), 32.0$ (C-7), 101.5 (C-6), 109.9 (C-4”), 116.6 (C-3”), 127.1 (C-4'), 
129.0 (C-3'/5'), 129.1 (C-2'/6'), 131.9 (C-3), 137.6 (C-1'), 138.5 (C-4), 144.8 (C-5), 147.9 ( C-2”), 154.7 (C-5”), 170.0 (C-2). HRMS (ESI) Calcd for $\mathrm{C}_{17} \mathrm{H}_{14} \mathrm{NaO}_{3}(\mathrm{M}+\mathrm{Na}), 289.0835$; Found, 289.0827.

(E)-3-Benzyl-5-(5-methylfuran-2-ylmethylene)furan-2(5H)-one (12b). The compound degraded in the presence of silica during isolation by HPLC, using eluent DCM/hexane (1:1 v/v) is not possible to obtain all spectra. ${ }^{1} \mathrm{H}$ NMR $\left(300 \mathrm{MHz}, \mathrm{C}_{6} \mathrm{D}_{6}\right), \delta 1.69\left(\mathrm{~s}, 3 \mathrm{H}, \mathrm{CH}_{3}\right), 3.41(\mathrm{~s}, 2 \mathrm{H}$,

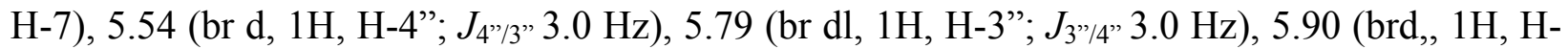
6), 7.58-7.61 (m, Ph, H-4). HRMS (ESI) Calcd for $\mathrm{C}_{17} \mathrm{H}_{14} \mathrm{NaO}_{3}(\mathrm{M}+\mathrm{Na}), 289.0835$; Found, 289.0827.

(Z)-3-Benzyl-5-(5-ethylfuran-2-ylmethylene)furan-2(5H)-one (13a). Yield 62\% (Z:E 30:70), diastereomers obtained after purification by column chromatography, eluent DCM /hexane (1:1 $\mathrm{v} / \mathrm{v})$. Orange amorphous solid, isolated by HPLC, eluent DCM /hexane (1:1 v/v). IR (neat) 3062, 3029, 2973, 2937, 1755, 1647, 1514, 1494, $1014 \mathrm{~cm}^{-1} .{ }^{1} \mathrm{H}$ NMR (300 MHz, $\left.\mathrm{C}_{6} \mathrm{D}_{6}\right), \delta 0.97$ (t, 3H, $\left.\mathrm{CH}_{3} ; J_{\mathrm{CH} 3 / \mathrm{CH} 2} 7.5 \mathrm{~Hz}\right), 2.32$ (q, 2H, $\left.\mathrm{CH}_{2} ; J_{\mathrm{CH} 2 / \mathrm{CH} 3} 7.5 \mathrm{~Hz}\right), 3.33$ (s, 2H, H-7), 5.41 (s, 1H, H-6), 5.79-5.81 (m, 1H, H-4"), 6.02-6.03 (m, 1H, H-4), 6.89-7.12 (m, 6H, Ph, H-3"). ${ }^{13} \mathrm{C}$ NMR (75 $\left.\mathrm{MHz}, \mathrm{C}_{6} \mathrm{D}_{6}\right), \delta 11.8\left(\mathrm{CH}_{3}\right), 21.6\left(\mathrm{CH}_{2}\right), 31.8$ (C-7), 100.5 (C-6), 108.3 (C-4’), 115.89 (C-3'/5'), 127.57 (C-4'), 128.8 (C-2'/6'), 128.2-128.8 (C-3), 129.1 (C-3’), 131.9 (C-1'), 137.8 (C-4), 145.3 (C-5), 148.1 (C-2”), 159.4 (C-5”), 169.4 (C-2). HRMS (ESI) Calcd for $\mathrm{C}_{18} \mathrm{H}_{16} \mathrm{NaO}_{3}(\mathrm{M}+\mathrm{Na}), 303.0992$; Found, 303.0983 .

(E)-3-Benzyl-5-(5-ethylfuran-2-ylmethylene)furan-2(5H)-one (13b). Yield 62\% (Z:E 30:70), diastereoisomers obtained after purification by column chromatography, eluent DCM /hexane $(1: 1 \mathrm{v} / \mathrm{v})$. Orange amorphous solid; isolated by HPLC, eluent DCM /hexane (1:1 v/v). IR (KBr) 3062, 3029, 2974, 2937, 1744, 1600, 1495, 1454, 1319, 1265, $1015 \mathrm{~cm}^{-1}$. ${ }^{1} \mathrm{H}$ NMR (300 MHz, $\left.\mathrm{CDCl}_{3}\right), \delta 1.19\left(\mathrm{t}, 3 \mathrm{H}, \mathrm{CH}_{3} ; J_{\mathrm{CH} 3 / \mathrm{CH} 2} 7.6 \mathrm{~Hz}\right), 2.65\left(\mathrm{q}, 2 \mathrm{H}, \mathrm{CH}_{2} ; J_{\mathrm{CH} 2 / \mathrm{CH} 3} 7.6 \mathrm{~Hz}\right), 3.75(\mathrm{~s}, 2 \mathrm{H}, \mathrm{H}-$ 7), 6.03 (dt, 1H, H-4"; $J_{4}$ "/3" 3.3 Hz; $J_{4 " / C H 2} 0.9$ Hz), 6.25 (br s, 1H; H-6), 6.38 (d, 1H, H-3"; $J_{3}$ "/4" $3.3 \mathrm{~Hz}), 7.24-7.37$ (m, 5H, Ph), 7.65-7.66 (m, 1H, H-4). ${ }^{13} \mathrm{C} \mathrm{NMR}\left(75 \mathrm{MHz}, \mathrm{CDCl}_{3}\right), \delta 12.1\left(\mathrm{CH}_{3}\right)$, $21.8\left(\mathrm{CH}_{2}\right), 32.2$ (C-7), 102.1 (C-6), 107.4 (C-4”), 116.0 (C-3”), 127.1 (C-4'), 129.0 (C-3'/5'), 129.1 (C2'/6'), 134.0 (C-3), 137.0 (C-4), 137.6 (C-1'), 146.6 (C-5), 148.0 (C-2”), 160.6 (C-5”), 170.0 (C-2). HRMS (ESI) Calcd for $\mathrm{C}_{18} \mathrm{H}_{16} \mathrm{NaO}_{3}(\mathrm{M}+\mathrm{Na}), 303.0989$; Found, 303.0983.

(Z)-3-Benzyl-5-((5-(4-chlorophenyl)furan-2-yl)methylene)furan-2(5H)-one (14a). Yield 87\% ( $Z: E$ 58:42), diastereoisomers obtained after purification by column chromatography, eluent $\mathrm{DCM} /$ hexane $(2: 3 \mathrm{v} / \mathrm{v})$. Yellow solid, mp 156.5-158.1 ${ }^{\circ} \mathrm{C}$, isolated by HPLC, eluent DCM /hexane $(2: 1 \mathrm{v} / \mathrm{v})$ and recrystallization with a mixture of DCM /hexane. IR (KBr) 3098, 3032, 2922, 1749, 1641, 1474, 1452, 1373, 1283, $1036 \mathrm{~cm}^{-1} .{ }^{1} \mathrm{H}$ NMR $\left(300 \mathrm{MHz}, \mathrm{CDCl}_{3}\right), \delta 3.73(\mathrm{~s}$, 2H, H-7), 5.95 (s, 1H, H-6), 6.78 (d, 1H, H-4"; $J_{4}$ "/3" 3.6 Hz), 6.93 (m, 1H, H-4), 7.07 (d, 1H, H3"; $J_{3}$ "/4" 3.6 Hz), 7.25-7.38 (m, 7H, H-3"'/5'"; H-2'/6', H-3'/5', H-4'), 7.61-7.64 (m, 2H, H2""/6"”). ${ }^{13} \mathrm{C}$ NMR (75 MHz, CDCl 3 ), $\delta 32.1$ (C-7), 100.9 (C-6), 109.3 (C-3"), 117.4 (C-4"), 125.5 (C2"'/6"'), 127.2 (C-4'), 128.7 (C-3"'/5"'), 129.1 (C-3'/5'), 129.2 (C-2'/6'), 129.3 (C-1”'), 132.7 (C-3), 134.0 (C-1'), 137.4 (C-4”’), 138.3 (C-4), 146.0 (C-5), 149.2 (C-2”), 154.1 (C-5”), 170.0 (C-2). HRMS (ESI) Calcd for $\mathrm{C}_{22} \mathrm{H}_{15} \mathrm{ClNaO}_{3}(\mathrm{M}+\mathrm{Na}), 385.0602$; Found, 385.0592 . 
(E)-3-Benzyl-5-(5-(4-chlorophenyl)furan-2-yl)methylene)furan-2(5H)-one (14b). Yellow solid, mp 202.3-204.0 ${ }^{\circ} \mathrm{C}$, purified by HPLC, eluent DCM /hexane $(2: 1 \mathrm{v} / \mathrm{v})$ and recrystallization with a mixture of DCM /hexane. IR (KBr) 3059, 2925, 1730, 1597, 1473, 1258, 1150, $1030 \mathrm{~cm}^{-1}$. ${ }^{1} \mathrm{H}$ NMR (300 MHz, $\mathrm{CDCl}_{3}$ ), $\delta 3.78$ (s, 2H, H-7), 6.29 (s, 1H, H-6), 6.53 (d, 1H, H-3"; $J_{3}$ "/4" 3.6 Hz), 6.66 (d, 1H, H-4"; $J_{4 \prime / 3}$ " 3.6 Hz), 7.32-7.44 (m, 9H, H-2"'/6"', H-3"'/5"', H-2'/6', H-3'/5', H-4'), 7.61-7.62 (m, 1H, H-4). ${ }^{13} \mathrm{C}$ NMR (75 MHz, $\mathrm{CDCl}_{3}$ ), $\delta 32.5$ (C-7); 101.2 (C-6), 108.5 (C-4”), 116.9 (C-3"), 125.3 (C-2"'/6"'), 127.72 (C-4'), 129.1 (C-3”"/5"'), 129.3 (C-3'/5'), 129.4 (C-2'/6'), 132.7 (C-1"'), 135.6 (C-1"'), 137.3 (C-1'), 137.4 (C-3), 136.8 (C-4), 147.7 (C-5), 149.6 (C-2”), 154.7 (C-5”), 169.4 (C-2). HRMS (ESI) Calcd for $\mathrm{C}_{22} \mathrm{H}_{15} \mathrm{ClNaO}_{3}(\mathrm{M}+\mathrm{Na}), 385.0602$; Found, 385.0590.

(Z)-3-Benzyl-5-((5-(4-bromophenyl)furan-2-yl)methylene)furan-2(5H)-one (15a). Yield 99\% ( $Z: E$ 69:31), diastereoisomers obtained after purification by column chromatography, eluent DCM/hexane (1:1 v/v). Yellow solid, mp 172.8-174.9 ${ }^{\circ} \mathrm{C}$, isolated by HPLC, eluent DCM /hexane $(1: 1 \mathrm{v} / \mathrm{v})$ and recrystallization with a mixture of DCM /hexane. IR (KBr) 3029, 2922, 2854, 1741, 1599, 1471, $1028 \mathrm{~cm}^{-1} .{ }^{1} \mathrm{H}$ NMR (300 MHz, $\left.\mathrm{CDCl}_{3}\right), \delta 3.73$ (s, 2H, H-7), 5.94 (s, $1 \mathrm{H}, \mathrm{H}-6), 6.79$ (d, 1H, H-4"; $J_{4}$ "/3" $\left.3.6 \mathrm{~Hz}\right), 6,93$ (t, 1H; H-4; $J_{4 / 7} 1.2 \mathrm{~Hz}$ ), 7.07 (d, 1H; H-3"; $J_{3}$ "/4" $3.6 \mathrm{~Hz}$ ), 7.25-7.58 (m, 9H, H-2'"/6'”, H-3"'/5'", H-2'/6', H-3'/5', H-4'). ${ }^{13} \mathrm{C}$ NMR (75 MHz, $\mathrm{CDCl}_{3}$ ), $\delta 32.1$ (C-7), 100.9 (C-6), 109.4 (C-4”), 117.4 (C-3”), 122.15 (C-4"”), 125.7 (C-2"'/6"'), 127.2 (C-4'), 129.0 (C-3'”/5'”), 129.1 (C-3'/5'), 132.2 (C-2'/6'), 132.7 (C-1'”), 137.3 (C-3), 137.4 (C-1'), 138.3 (C-4), 146.1 (C-5), 149.2 (C-2”), 154.2 (C-5”), 170.1 (C-2). HRMS (ESI) Calcd for $\mathrm{C}_{22} \mathrm{H}_{15} \mathrm{BrNaO}_{3}$ $(\mathrm{M}+\mathrm{Na}), 431.0082$; Found, 431.0083.

(E)-3-Benzyl-5-((5-(4-bromophenyl)furan-2-yl)methylene)furan-2(5H)-one (15b). Yellow solid, mp 204.5-206.9 ${ }^{\circ} \mathrm{C}$, purified by HPLC, eluent DCM/hexane $(1: 1 \mathrm{v} / \mathrm{v})$ and recrystallization with a mixture of DCM/hexane. IR (KBr) 3060, 3028, 1743, 1645, 1600, 1471, 1238, 1073, 1036 $\mathrm{cm}^{-1} .{ }^{1} \mathrm{H}$ NMR (300 MHz, $\mathrm{CDCl}_{3}$ ), $\delta 3.78$ (s, 2H, H-7), 6.28 (s, 1H, H-6), 6.52 (d, 1H, H-3"; $J_{4}$ "/3" $3.6 \mathrm{~Hz}$ ), 6.67 (d, 1H, H-4"; $J_{4}$ "/3" 3.6 Hz), 7.24-7.49 (m, 9H, H-2"'/6"', H-3"'/5"', H-2'/6', H-3'/5', H-4'), 7.60-7,61 (m, 1H, H-4). ${ }^{13} \mathrm{C}$ NMR (75 MHz, CDCl 3 ), $\delta 32.5$ (C-7), 101.8 (C-6), 108.5 (C-4”), 116.9 (C-3”), 122.3 (C-4"'), 125.5 (C-2"'/6"'), 128.7 (C-4'), 129.1( C-3"'/5"'), 129.4 (C-3'/5'), 132.3 (C-2'/6'), 135.6 (C-1'”), 137.3 (C-1'), 137.4 (C-3), 136.79 (C-4), 147.7 (C-5), 149.6 (C-2”), 154.7 (C-5”), 169.4 (C-2). HRMS (ESI) Calcd for $\mathrm{C}_{22} \mathrm{H}_{15} \mathrm{BrNaO}_{3}(\mathrm{M}+\mathrm{Na}), 431.0082$; Found, 431.0092.

(Z)-3-Benzyl-5-((5-(2-nitrophenyl)furan-2-yl)methylene)furan-2(5H)-one (16a). Yield 48\% ( $Z: E$ 63:37), diastereoisomers obtained after purification by column chromatography, eluent $\mathrm{DCM} /$ hexane (1:1 v/v). Dark yellow solid, mp 114.4-114.9 ${ }^{\circ} \mathrm{C}$, isolated by HPLC, eluent DCM /hexane $(3: 1 \mathrm{v} / \mathrm{v})$ and recrystallization with a mixture of DCM /hexane. IR ( $\mathrm{KBr}) 3064,3030$, 2923, 1757, 1604, 1525, 1495, 1456, 1352, 1270, $1019 \mathrm{~cm}^{-1} .{ }^{1} \mathrm{H}$ NMR $\left(300 \mathrm{MHz}, \mathrm{CDCl}_{3}\right), \delta 3.72$

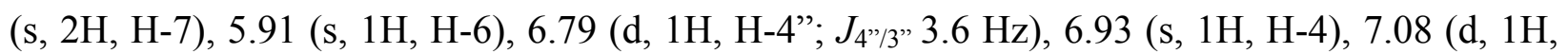
H-3"; $J_{3}$ "/4" $3.6 \mathrm{~Hz}$ ), 7.24-7.77 (m, 9H, H-2"'/6"', H-3"'/5"', H-2'/6', H-3'/5', H-4'). ${ }^{13} \mathrm{C}$ NMR (75 MHz, $\mathrm{CDCl}_{3}$ ), $\delta 31.8$ (C-7), 100.2 (C-6), 113.0 (C-4"), 116.6 (C-3”), 123.4 (C-3), 124.0 (C-6"'), 127.0 (C-4'), 128.7 (C-3"'), 128.8 (C-5"'), 128.9 (C-3'/5'), 129.0 (C-2'/6'), 132.9 (C-4"'), 133.2 (C-1"'), 137.0 (C-1'), 138.0 (C-4), 146.6 (C-5), 147.4 (C-2"”), 149.1 (C-5”), 150.2 (C-2”), 169.7 (C-2). HRMS (ESI) Calcd for $\mathrm{C}_{22} \mathrm{H}_{15} \mathrm{NNaO}_{5}(\mathrm{M}+\mathrm{Na}), 396.0842$; Found, 396.0850. 
(E)-3-Benzyl-5-((5-(2-nitrophenyl)furan-2-yl)methylene)furan-2(5H)-one (16b). Yellow solid, mp 122.4-122.7 ${ }^{\circ} \mathrm{C}$, purified by HPLC, eluent DCM /hexane (3:1 v/v) and recrystallization with a mixture of DCM /hexane. IR (KBr) 3063, 2925, 1763, 1605, 1529, 1461, 1359, 1283, $1030 \mathrm{~cm}^{-1} .{ }^{1} \mathrm{H}$ NMR $\left(300 \mathrm{MHz}, \mathrm{CDCl}_{3}\right), \delta 3.78$ (s, 2H, H-7), 6.29 (s, 1H, H-6), 6.56 (d, 1H, H3"; $J_{4} " / 3$ " $3.3 \mathrm{~Hz}$ ), 6.75 (d, 1H, H-4"; $J_{4}$ "/3" $3.3 \mathrm{~Hz}$ ), 7.25-7.70 (m, 10H, H-2" "/6", H-3"'/5", H2'/6', H-3'/5', H-4', H-4). ${ }^{13} \mathrm{C} \mathrm{NMR}$ (75 MHz, $\mathrm{CDCl}_{3}$ ), $\delta 32.3$ (C-7), 101.8 (C-6), 112.4 (C-4'), 116.4 (C-3”), 123.6 (C-3), 124.2 (C-6"'), 127.0 (C-4'), 128.7 (C-3"”), 129.0 (C-5"'), 129.0 (C-3'/5'), 129.3 (C2'/6'), 132.2 (C-4"'), 135.6 (C-1'”), 137.5 (C-1'), 146.6 (C-2'”), 146.8 (C-4), 147.7 (C-5”), 150.3 (C-5), 151.0 (C-2"), 169.5 (C-2). HRMS (ESI) Calcd for $\mathrm{C}_{22} \mathrm{H}_{15} \mathrm{NNaO}_{5}(\mathrm{M}+\mathrm{Na}), 396.0842$; Found, 396.0850 .

(Z)-3-benzyl-4-isopropyl-5-(4-nitrobenzylidene)furan-2(5H)-one (17). Yield 36\%, yellow solid, mp 90.0-91.0 ${ }^{\circ} \mathrm{C}$. IR (neat) 3070, 2925, 2850, 1768, 1518, 1435, 1110, $1075 \mathrm{~cm}^{-1}$. ${ }^{1} \mathrm{H}$ NMR $\left(300 \mathrm{MHz}, \mathrm{CDCl}_{3}\right.$ ), $\delta 1.34$ (d, 6H, H-2' '; J7.0 Hz), 3.19 (sept, $1 \mathrm{H}, \mathrm{H}-1$ ' '; J 7.0 Hz), 3.83 (s, 2H, H-7), 6.20 (s, 1H, H-6), 7.21-7.34 (m, 5H, H-2'/H-6'), 7.93 (d, 2H, H-2"'/H-6'"; J 9.1 Hz), 8.22 (d, 2H, H-3"'/H-5"'; J 9.1 Hz). ${ }^{13} \mathrm{C}$ NMR (75 MHz, CDCl $), \delta 21.8$ (C-2"), 26.8 (C-1' '), 30.1 (C7), 107.7(C-6), 123.1 (C-3'”/C-5'”'), 127.1 (C-4'), 128.6 (C-3'/C-5'), 129.1 (C-2'/C-6'), 131.1 (C-2"”/C-6"'), 135.0 (C-1"”), 137.8 (C-1'), 139.2 (C-3), 139.9 (C-4"”), 149.9 (C-4), 157.6 (C-5), 170.0 (C-2). HRMS (ESI) Calcd for $\mathrm{C}_{21} \mathrm{H}_{19} \mathrm{NNaO}_{4}{ }^{+}$(M+Na), 372.1206; Found, 372.1193.

5(Z)-3-benzyl-4-isopropyl-5-(3-nitrobenzylidene)furan-2(5H)-one (18). Yield 83\%, yellow solid, mp 124.5-125.5 ${ }^{\circ} \mathrm{C}$. IR (neat) 3100, 3080, 1766, 1645, 1615, 1531, 1495, 1350, 1099, $1033 \mathrm{~cm}^{-1} .{ }^{1} \mathrm{H}$ NMR (300 MHz, $\mathrm{CDCl}_{3}$ ), $\delta 1.34$ (d, 6H, H-2"; $J 7.0 \mathrm{~Hz}$ ), 3.19 (sept, 1H, H-1 ' ; $J$ 7.0 Hz), 3.83 (s, 2H, H-7), 6.20 (s, 1H, H-6), 7.20-7.32 (m, 5H, H-2'-H-6'), 7.57 (t, 1H, H-5'"; $J$ $8.0 \mathrm{~Hz}$ ), 8.13 (ddd, 1H, H-4"'; J 2.1 Hz, J 0.9 Hz, J 8.0 Hz), 8.17 (br d, 1H, J 8.0 Hz, H-6"'), 8.44 (t, 1H, H-2', '; $2.1 \mathrm{~Hz}) .{ }^{13} \mathrm{C}$ NMR (75 MHz, CDCl $), \delta 21.8$ (C-2' '), 26.8 (C-1' '), 29.9 (C7), 107.7 (C-6), 123.1 (C-4”’), 125.1 (C-6’”), 126.9 (C-4'), 128.5 (C-3'/C-5'), 129.0 (C-2'/C-6'), 130.0 (C-3"”), 135.1 (C-1'”), 136.0 (C-3), 138.0 (C-2”’), 136.7 (C-1'), 139.1 (C-4), 157.6 (C-5), 149.2 (C-5"), 170.0 (C-2). HRMS (ESI) Calcd for $\mathrm{C}_{21} \mathrm{H}_{19} \mathrm{NNaO}_{4}{ }^{+}(\mathrm{M}+\mathrm{Na}), 372.1206$; Found, 372.1192 .

(Z)-3-Benzyl-4-isopropyl-5-(4-trifluoromethylbenzylidene)furan-2(5H)-one (19). Yield 22\%, White solid, $\mathrm{mp} 83.5-84.0^{\circ} \mathrm{C}$. IR (neat) $3030,2975,2930,1769,1649,1615,1495,1416,1324$, $1165 \mathrm{~cm}^{-1} .{ }^{1} \mathrm{H}$ NMR (300 MHz, $\left.\mathrm{CDCl}_{3}\right), \delta 1.34$ (d, 6H, H-2', $\left.J 7.2 \mathrm{~Hz}\right), 3.18$ (sept, 1H, H-1 ' ; $J$ $7.2 \mathrm{~Hz}$ ), 3.83 (s, 2H, H-7), 6.21 (s, 1H, H-6), 7.20-7.32 (m, 5H, H-2'-H-6' ), 7.62 (d, 2H, H3"'/H-5" ; J $8.4 \mathrm{~Hz}), 7.88$ (d, 2H, H-2"'/H-6"”; J 8.4 Hz). ${ }^{13} \mathrm{C}$ NMR (75 MHz, CDCl $), \delta 21.9(\mathrm{C}-$ 2'), 26.8 (C-1'), 29.9 (C-7), 108.7 (C-6), 125.9 (q, C-3"'/C-5"'; J, J $3.8 \mathrm{~Hz}), 126.0\left(\mathrm{CF}_{3}\right)$, 126.9 (C4'), 128.5 (C-2'/C-6'), 128.9 (C-3'/C-5'), 130.5 (C-4'”'), 130.7 (C-2'”/C-6','), 134.0 (C3), 136.5 (C-1"'), 136.8 (C-1'), 138.0 (C-4), 157.8 (C-5), 170.3 (C-2). HRMS (ESI) Calcd for $\mathrm{C}_{22} \mathrm{H}_{19} \mathrm{~F}_{3} \mathrm{O}_{2}(\mathrm{M}+1)$, 373.1371. HRMS (ESI) Calcd for $\mathrm{C}_{22} \mathrm{H}_{19} \mathrm{~F}_{3} \mathrm{NaO}_{2}{ }^{+}(\mathrm{M}+\mathrm{Na}), 395.1229$; Found, 395.1220.

(Z)-3,4-Dichloro-5-(3,4-metylenedioxybenzylidene)furan-2(5H)-one (20). Yield 70\%, yellow solid, mp 159.5-160.2 ${ }^{\circ} \mathrm{C}$. IR (neat) 3078, 2919, 1769, 1652, 1618, 1570, 1503, 1453, 1269 , 
1254, $1108 \mathrm{~cm}^{-1} .{ }^{1} \mathrm{H}$ NMR $\left(300 \mathrm{MHz}, \mathrm{CDCl}_{3}\right), \delta 6.04\left(\mathrm{~s}, 2 \mathrm{H},-\mathrm{OCH}_{2} \mathrm{O}-\right), 6.32(\mathrm{~s}, 1 \mathrm{H}, \mathrm{H}-6), 6.84$ (d, 1H, H-5'; J 8.1 Hz), 7.18 (dd, 1H, H-6'; J 8.1 Hz, J $1.8 \mathrm{~Hz}), 7.44$ (d, 1H, H-2'; J $1.8 \mathrm{~Hz}) .{ }^{13} \mathrm{C}$ NMR (75 MHz, $\mathrm{CDCl}_{3}$ ), $\delta 102.1$ (-Oㅡㄹ $\left.{ }_{2} \mathrm{O}-\right), 109.2$ (C-5'), 110.5 (C-2'), 113.0 (C-6), 126.2 (C6'), 127.4 (C-3), 130.2 (C-1'), 132.3 (C-4), 148.7 (C-3'), 149.8 (C-4'), 161.5 (C-5), 162.4 (C-2).

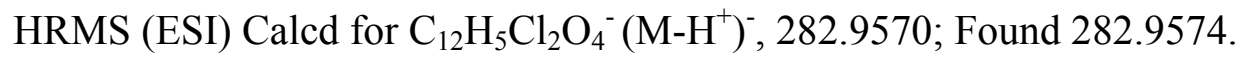

(Z)-5-(Benzo[d][1,3]dioxol-5-ylmethylene)-3,4-dibromofuran-2(5H)-one (21). Yield 65\%, yellow solid, mp 170.7-171.5 ${ }^{\circ} \mathrm{C}$; IR (neat) 3078, 2918, 1769, 1650, 1569, 1502, 1269, 1254, $1106 \mathrm{~cm}^{-1} .{ }^{1} \mathrm{H}$ NMR $\left(300 \mathrm{MHz}, \mathrm{CDCl}_{3}\right), \delta 6.05$ (s, 2H, -O-C $\left.\underline{\mathrm{H}}_{2}-\mathrm{O}-\right), 6.36$ (s, 1H, H-6), 6.85 (d, 1H, H-5'; J $8.1 \mathrm{~Hz}), 7.22$ (dd, 1H, H-6'; $J 8.1 \mathrm{~Hz}, J 1.8 \mathrm{~Hz}), 7.46$ (d, 1H, H-2'; J $1.8 \mathrm{~Hz}) .{ }^{13} \mathrm{C}$ NMR (75 MHz, CDCl $), \delta 101.8$ (-O- $\left.\underline{C H}_{2}-\mathrm{O}-\right), 108.5$ (C-5'), 109.0 (C-2'), 110.3 (C-6), 125.4 (C6'), 127.5 (C-3), 129.9 (C-1'), 132.0 (C-4), 148.7 (C-3'), 149.8 (C-4'), 161.1 (C-2), 162.0 (C-5). HRMS (ESI) Calcd for $\mathrm{C}_{12} \mathrm{H}_{5} \mathrm{Br}_{2} \mathrm{NaO}_{4}^{-}\left(\mathrm{M}-\mathrm{H}^{+}\right), 370.8560$; Found 370.8562

(Z)-3,4-Dibromo-5-(4-nitrobenzylidene)furan-2(5H)-one (22). Yield 13\%, yellow solid, mp 188.1-189.0 ${ }^{\circ} \mathrm{C}$. IR (neat) $3040,1725,1593,1609,1518,1345,1108,1024 \mathrm{~cm}^{-1} .{ }^{1} \mathrm{H}$ NMR $(300$ $\mathrm{MHz} \mathrm{CDCl}_{3}$ ), $\delta 6.77$ (s, 1H, H-6), 8.01 (d, 2H, H-3'/H-5'; J $9.0 \mathrm{~Hz}$ ), 8.28 (d, 2H, H-2'/H-6'; $J$ $9.0 \mathrm{~Hz}) .{ }^{13} \mathrm{C} \mathrm{NMR}\left(75 \mathrm{MHz}, \mathrm{CDCl}_{3}\right), \delta 105.0$ (C-6), 119.1 (C-3), 123.8 (C-3'/C-5'), $129.8(\mathrm{C}-$ 2'/C-6'), 135.3 (C-4), 137.0 (C-1'), 146.0 (C-5), 148.5 (C-4'), 158.3 (C-2). HRMS (ESI) Calcd for $\mathrm{C}_{11} \mathrm{H}_{4} \mathrm{Br}_{2} \mathrm{NO}_{4}{ }^{-}\left(\mathrm{M}-\mathrm{H}^{+}\right)^{-}, 371.8513$; Found 371.8510 .

(Z)-3-Benzyl-5-((E)-3-phenylallylidene)furan-2(5H)-one (23). Yield 32\%, yellow solid, mp 112.0 - $112.8^{\circ} \mathrm{C}$. IR (neat) 3086, 3059, 3030, 2923, 1759, 1630, 1594, 1570, 1496, 1457, 1328, $1032 \mathrm{~cm}^{-1} .{ }^{1} \mathrm{H}$ NMR (300 MHz, $\mathrm{CDCl}_{3}$ ), $\delta 3.73$ (br s, 2H, H-9), 5.85 (d, 1H, H-6; J6/7 $11.4 \mathrm{~Hz}$ ), 6.74 (d, 1H, H-8; $J_{8 / 7} 15.6$ Hz), 6.89 (t, 1H, H-4; $J_{4 / 9} 1.3$ Hz), 7.25-7.40 (m, 9H, H-7, H-2'/H-6', H-3'/H5", H-3"/H-5"), 7.42-7.46 (m, 2H, H-2"/6"). ${ }^{13} \mathrm{C}$ NMR (75 MHz, CDCl 3 ), $\delta 32.2$ (C-9), 113.9 (C-6), 121.9 (C-7), 127.2 (C-3), 127.3 (C-4'), 127.4 (C-2”/6”), 129.0 (C-3”/5”), 129.1 (C-2'/6'), 129.2 (C-3'/5'), 129.3 (C-4”), 133.47 (C-1”), 136.73 (C-1'), 137.45 (C-8), 137.71(C-4), 148.19 (C-5), 169.98 (C-2). HRMS (ESI) Calcd $\mathrm{C}_{20} \mathrm{H}_{16} \mathrm{NaO}_{2}(\mathrm{M}+\mathrm{Na}), 311.1043$; Found 311.1033

Biological assays. The ability to interfere with the photosynthetic electron transport chain was evaluated on photosynthetically active thylakoid membranes isolated from market spinach (Spinacia oleracea L.) leaves. Deveined plant material was resuspended in $5 \mathrm{~mL} \mathrm{~g}^{-1}$ of ice-cold $20 \mathrm{mM}$ N-tris(hydroxymethyl)methylglycine (Tricine)-NaOH buffer ( $\mathrm{pH} \mathrm{8.0)}$ containing $10 \mathrm{mM}$ $\mathrm{NaCl}, 5 \mathrm{mM} \mathrm{MgCl}$, and $0.4 \mathrm{M}$ sucrose, and homogenized for $30 \mathrm{~s}$ in a blender at maximal speed. The homogenate was filtered through surgical gauze, and the filtrate was centrifuged at 4 ${ }^{\circ} \mathrm{C}$ for $1 \mathrm{~min}$ at $500 \mathrm{~g}$; the supernatant was further centrifuged for $10 \mathrm{~min}$ at $1500 \mathrm{~g}$. Pelleted chloroplasts were osmotically swollen by resuspension in sucrose-lacking buffer. The suspension was immediately diluted 1:1 with sucrose-containing buffer, kept on ice in the dark, and used within a few hours from preparation. Following proper dilution with $80 \%(\mathrm{v} / \mathrm{v})$ acetone, the absorbance of each sample was determined at 645 and $663 \mathrm{~nm}$, and the chlorophyll content was calculated on the basis of Arnon's formula. 
The basal rate of photosynthetic electron transport was measured following light-driven ferricyanide reduction. Aliquots of membrane preparations corresponding to $15 \mu \mathrm{g}$ of chlorophyll were incubated at $24{ }^{\circ} \mathrm{C}$ in $1 \mathrm{~mL}$ cuvettes containing $20 \mathrm{mM}$ Tricine- $\mathrm{NaOH}$ buffer (pH 8.0), $10 \mathrm{mM} \mathrm{NaCl}, 5 \mathrm{mM} \mathrm{MgCl} 2,0.2 \mathrm{M}$ sucrose, and $1 \mathrm{mM} \mathrm{K}_{3} \mathrm{Fe}(\mathrm{CN})_{6}$. The assay was initiated by exposure to saturating light $\left(800 \mu \mathrm{mol} \mathrm{m}^{-2} \mathrm{~s}^{-1}\right)$, and the rate of ferricyanide reduction was measured at $1 \mathrm{~min}$ intervals for $10 \mathrm{~min}$ against an exact blank at $420 \mathrm{~nm}$. Activity was calculated over the linear portion of the curve from a molar extinction coefficient of $1000 \mathrm{M}^{-1}$ $\mathrm{cm}^{-1}$. The mean value $( \pm \mathrm{SD})$ for untreated controls was $73.2 \pm 7.4 \mathrm{nmol} \mathrm{s}^{-1}\left(\mathrm{mg}\right.$ of chlorophyll) ${ }^{-1}$ in 18 independent thylakoid membrane preparations. Nostoclide analogues were dissolved in DMSO so as to obtain $10 \mathrm{mM}$ solutions that were then water diluted, as appropriate. Their effect upon the photosynthetic electron transport was evaluated in parallel assays in which the compounds were added to the reaction mixture to a final concentration of $1,2,5,10,20,50$ or $100 \mu \mathrm{M}$. For each dose the assay was carried out in triplicate. The concentrations causing 50\% inhibition $\left(\mathrm{IC}_{50}\right)$ were estimated utilizing the linear regression equation of activity values, expressed as percentage of untreated controls, plotted against the logarithm of inhibitor concentration. Confidence limits were computed according to Snedecor and Cochran. ${ }^{26}$

Phosphorylating electron flow was assessed under the same conditions, but in the presence of 0.5 $\mathrm{mM} \mathrm{ADP}$ and $2 \mathrm{mM} \mathrm{K}_{2} \mathrm{HPO}_{4}$. Unless otherwise indicated, uncoupled activity was measured following the addition of $0.5 \mathrm{mM} \mathrm{NH} \mathrm{NCl}_{4}$ to the basal reaction mixture containing aliquots of membrane preparations corresponding to $7.5 \mu \mathrm{g}$ chlorophyll.

\section{Acknowledgements}

The authors thank Drs. Andrea Duzzi and Alice Donà for technical assistance and Dr. Akshat Rati from University of Oxford for HRMS data. Support from the University of Ferrara (Fondo di Ateneo per la Ricerca 2010) is acknowledged. We are also grateful to the following Brazilian agencies: Conselho Nacional de Desenvolvimento Científico e Tecnológico (CNPq) for research fellowships (AJD, CRAM, LCAB), Fundação de Amparo à Pesquisa de Minas Gerais (FAPEMIG), Coordenação de Aperfeiçoamento de Pessoal de Nível Superior (CAPES, PROCAD program, Grant 23038.022059/2008-92) and FINEP for financial support.

\section{References}

1. (a) Duke, S. O.; Dayan, F. E.; Rimando, A. M.; Schrader, K. K.; Aliotta, G.; Oliva, A.; Romagni, J. G. Weed Sci. 2002, 50, 138. (b) Dayan, F. E.; Cantrell, C. L.; Duke, S. O. Bioorg. Med. Chem. 2009, 17, 4022. 
2. (a) Barbosa, L. C. A.; Demuner, A. J.; Alvarenga, E. S.; Oliveira, A.; King-Diaz, B.; Lontina-Hennsen, B. Pest Manag. Sci. 2006, 62, 214. (b) Costa, A. V.; Brabosa, L. C. A.; Demuner, A. J.; Silva, A. A. J. Agric. Food Chem. 1999, 47, 4807.

3. (a) Owen, M. D. K.; Zelaya, I. A. Pest Manag. Sci. 2005, 61, 301. (b) Heap, I. The International Survey of Herbicide Resistant Weeds. April 27, 2011. Available online at http://www.weedscience.com.

4. Rüegg, W. T.; Quadranti, M.; Zoschke, A. Weed Res. 2007, 47, 271.

5. Heri, W.; Pfister, F.; Carroll, B.; Parshley, T.; Nabors, J. B. In The Triazine Herbicides: 50 Years Revolutionizing Agriculture; LeBaron, H. M.; McFarland, J. E.; Burnside, O. Eds.; Elsevier: San Diego CA, 2008; p. 31. (b). Wang, J. G.; Li, Z. M.; Ma, N.; Wang, B. L.; Jiang, L.; Pang, S. S.; Lee, Y. T.; Guddat, L. W.; Duggleby, R. G. J. Comput.-Aided Mol. Des. 2005, 19, 801. (c) Ladner, D. W. Pest Manag. Sci. 1990, 29, 317.

6. (a) Barbosa, L. C. A.; Demuner, A. J.; Maltha, C. R. A.; Silva, P. S.; Silva, A. A. Quim. Nova 2003, 26, 655. (b) Lima, L. S.; Barbosa, L. C. A.; Alvarenga, E. S.; Demuner, A. J.; Silva, A. A. Aust. J. Chem. 2003, 56, 625.

7. (a) Xuemin, Y.; Yuzuru, S.; Steiner, J. R.; Clardy, J. Tetrahedron Lett. 1993, 34, 761. (b) Teixeira, R. R.; Barbosa, L. C. A.; Santana, J. O.; Veloso, D. P.; Ellena, J.; Doriguetto, A. C.; Drew, M. G. B.; Ismail, F. M. D. J. Mol. Struct. 2007, 837, 197.

8. (a) Pignatello J. J.; Porwoll J.; Carlson R. E.; Xavier A.; Gleason F. K.; Wood J. M. J. Org. Chem. 1983, 48, 4035. (b) Gleason, F. K. FEMS Microbiol. Lett. 1990, 68, 77. (c) Smith, G. D.; Doan, N. T. J. Appl. Phycol. 1999, 11, 337.

9. Barbosa, L. C. A.; Rocha, M. E.; Teixeira, R. R.; Maltha, C. R. A.; Forlani, G. J. Agric. Food Chem. 2007, 55, 8562.

10. Teixeira, R. R.; Barbosa, L. C. A.; Forlani, G.; Piló-Veloso, D.; de Mesquita Carneiro, J. W. J. Agric. Food Chem. 2008, 56, 2321.

11. (a) Hess, F. D. Weed Sci. 2000, 48, 160. (b) Trebst, A. Photosynth. Res. 2007, 92, 217.

12. (a) Castaneda, P.; Mata, R.; Lotina-Hennsen, B. J. Sci. Food Agric. 1998, 78, 102. (b) Macias, M. L.; Rojas, I. S.; Mata, R.; Lotina-Hennsen, B. J. Agric. Food Chem. 1999, 47, 2137.

13. Teixeira, R. R.; Pinheiro, P. F.; Barbosa, L. C. A.; de Mesquita Carneiro, J. W.; Forlani, G. Pest Manag. Sci. 2010, 66, 196.

14. (a) Kupatt, C. C. Jr. Two roles of thylakoid lipids in modifying the activity of herbicides which inhibit photosystem II. PhD Thesis, Rutgers-the State University: New Brunswick, NJ (USA), 1985. (b) Macias, F. A.; Marin, D.; Oliveros-Bastidas, A.; Molinillo, J. M. G. J. Agric. Food Chem. 2006, 54, 9357. (c) Donovan, S. F. ACS Symp. Ser. 2007, 948, 7.

15. (a) Dayan, F. E.; Vincent, A. C.; Romagni, J. G.; Allen, S. N.; Duke, S. O.; Duke, M. V.; Bowling, J. J.; Zjawiony, J. K. J. Agric. Food Chem. 2000, 48, 3689. (b) Vicentini, C. B.; Mares, D.; Tartari, A.; Manfrini, M.; Forlani, G. J. Agric. Food Chem. 2004, 52, 1898.

16. Näsman, J. H. Org. Synthesis 1990, 68, 162.

17. Boukouvalas, J.; Maltais, F.; Lachance, N. Tetrahedron Lett. 1994, 35, 7897. 
18. Bellina, F.; Rossi, R. Synthesis 2002, 2729.

19. (a) Negishi, E.; Hu, Q.; Huang, Z.; Qian, M.; Wang, G. Aldrichim. Acta 2005, 38, 71. (b) Han, C.; Buchwald, S. L. J. Am. Chem. Soc. 2009, 131, 7532.

20. Sarma, K. D.; Zhang, J.; Curran, T. T. J. Org. Chem. 2007, 72, 3311.

21. (a) Boukouvalas, J.; Pouliot, M. Synlett 2005, 343. (b) Boukouvalas, J.; Beltrán, P. P.; Lachance, N.; Côté, N.; Maltais, F.; Pouliot, M. Synlett 2007, 219 ; (c) Boukouvalas, J.; McCann, L. C. Tetrahedron Lett. 2010, 51, 4636.

22. Xu, H.; Wang, J.; Liu, G.; Hong, G.; Liu, H. Org. Biomol. Chem. 2007, 5, 1247.

23. Gleason, F.K.; Thoma, W.J.; Carlson, J. L. In Progress in Photosynthesis Research; Briggins, J., Ed.; Martinus Nijhoff: The Hague, 1987; Vol. 3, pp. 763-766.

24. Bellina, F.; Anselmi, C.; Stéphane, V.; Mannina, L.; Rossi, R. Tetrahedron 2001, 57, 9997.

25. Lipton, M. F.; Sorensen, C.M.; Sadler, A. C.; Shapiro, R. H. J. Organomet. Chem. 1980, $186,155$.

26. Snedecor, G. W.; Cochran, W. G. Statistical methods, $8^{\text {th }}$ ed.; The Iowa State University Press: Ames, IA, 1989.

27. Perrin, D. D.; Armarego, W. L. F. Purification of Laboratory Chemicals, 3rd ed.; Pergamon: Oxford, UK, 1988. 